\title{
Inhibition of Aromatase and Cell Proliferation of Breast Cancer and Human Placenta Choriocarcinoma by Prunus persica Extracts
}

\author{
N. DHINGRA*, A. KAR, AND R. SHARMA ${ }^{1}$ \\ School of Life Sciences, ${ }^{1}$ School of Pharmacy, Devi Ahilya University, Takshashila Campus, Indore-452 001, India
}

Dhingra et al.: Aromatase inhibition by Prunus persica extract

\begin{abstract}
Prunus persica has been used as a source of traditional medicine in many countries for the treatment of different diseases in females. In the present study, cytotoxicity and reactive oxygen species scavenging effects of Prunus persica extract on human breast cancer and placenta choriocarcinoma cell lines were evaluated. Besides this, regulations of oestrogen synthesis and antiaromatase activity were observed on human placenta choriocarcinoma cells. Ethyl acetate and butanol fractions had the maximum cytotoxic activity among all the fractions. In comparison to butanol fraction, ethyl acetate fraction was found to scavenge maximum intracellular reactive oxygen species, which was correlated with its total phenolic and flavonoid contents. Ethyl acetate was found to reduce the aromatase activity by $50 \%$ at the concentration of $200 \mu \mathrm{g} / \mathrm{ml}$. This inhibitory effect on aromatase was accompanied by reduced 17ß-estradiol levels in JEG-3 cells. It seemed that the ethyl acetate and n-butanol fractions of Prunus persica or its active compound appears to be acting through dual mechanisms, i.e. improvement of antioxidant system and by suppressing aromatase; it may potentially be used as therapeutic agent for the treatment of breast cancer. These findings suggested that Prunus persica extract could be an aromatase inhibitor for the treatment of oestrogen-sensitive breast cancer.
\end{abstract}

Key words: Prunus persica, aromatase, oestrogen synthesis, ROS scavenging, breast cancer

There is an overwhelming evidence that consumption of fruits and vegetables is related to their protective efficacy against several chronic diseases, including cancer. Yet nothing much has been studied in Prunus fruits. Prunus persica belongs to family Rosacea and has been known to exhibit various pharmacological activities such as inhibition of oxidative process, chemotherapy-induced acute nephrotoxicity, hepatotoxicity, fungal infection and allergic reaction ${ }^{[1]}$. The therapeutic role of its seed is well-known. It is used as a traditional medicine in Japan, China, and other Asian countries mainly for the treatment of different diseases in females, including premenstrual syndrome ${ }^{[2]}$. However, its role in the regulation of breast cancer was not well understood.

Oxidative stress is known to activate a variety of transcription factors including NF- $\kappa \mathrm{B}$, AP-1, p53, HIF-1 $\alpha$, PPAR- $\gamma, \beta$-catenin/Wnt and Nrf2, which lead to the expression of different genes, including those for growth factors, inflammatory cytokines, chemokines leading to transformation of a normal cell to tumor cell ${ }^{[3]}$. Polyphenols contribute significantly to

*Address for correspondence E-mail: navlifescience@gmail.com the total antioxidant capacity of fruits. Therefore, it is believed that the cellular system can be protected from oxidative stress by these polyphenols ${ }^{[4]}$ and polyphenol containing plant extracts might have potential as anticarcinogenic agents.

Oestrogen plays one of the major roles in breast cancer and aromatase enzyme, a member of cytochrome P450 superfamily, synthesizes oestrogen by converting androstenedione and testosterone to oestrone and oestradiol, respectively. It has also been reported that approximately $60 \%$ of premenopausal and $75 \%$ of postmenopausal patients have oestrogen-dependent carcinomas. But aromatase inhibition reduces the oestrogen levels and thus could be a viable therapeutic target for breast cancer patients. In fact, aromatase

This is an open access article distributed under the terms of the Creative Commons Attribution-NonCommercial-ShareAlike 3.0 License, which allows others to remix, tweak, and build upon the work non-commercially, as long as the author is credited and the new creations are licensed under the identical terms

Accepted 21 August 2018

Revised 22 February 2018

Received 09 March 2017

Indian J Pharm Sci 2018;80(5):903-910 
inhibitors (AIs) are recommended as the first-line therapy for postmenopausal and premenopausal breast cancer $^{[5-8]}$. However, long-term use of AIs increased the risk of skeletal problems, such as osteoporosis or bone fracture. Therefore, there is an urgent need to develop selective AIs with minimum side effects.

In the present investigation, the cytotoxic activity of different fractions of $P$. persica fruit in two human breast cancer cell lines, oestrogen receptor positive (MCF-7) and oestrogen receptor negative (MDAMB-468), and in human placenta choriocarcinoma cells (JEG-3) were evaluated. In one of our previous studies, the diversified antioxidant activities of different fractions of $P$. persica fruit $^{[9]}$ were reported. So to understand its antioxidant activity in breast cancer and human placenta choriocarcinoma cells, the intracellular reactive oxygen species (ROS) scavenging activity of the most potent cytotoxic fraction of $P$. persica and aromatase inhibition activity along with its regulatory potential of oestrogen synthesis were investigated. Further, the bioactive compounds from these fractions were isolated and evaluated for cytotoxic activity on human placenta choriocarcinoma cells. In fact, this is the first report on the intracellular ROS scavenging, aromatase and oestrogen synthesis inhibition of P. persica fruit fraction.

\section{MATERIAL AND METHODS}

\section{Plant collection:}

Fruits of Prunus persica (peach) were collected from Kullu, Himachal Pradesh, India, identified and a Voucher specimen PP-10/02 of this collection has been deposited in the School of Life Sciences, Devi Ahilya University, Indore, India. Fresh samples were used for the preparation of extract.

\section{Preparation of extracts:}

Seeds of Prunus persica were removed and flesh part was used for extraction. Fruits were extracted with $80 \%$ acetone in the ratio of $1: 10 \mathrm{w} / \mathrm{v}$ in a Warring blender for $5 \mathrm{~min}$ and then homogenized by polytron homogenizer for $3 \mathrm{~min}$. The residue left was processed thrice with the same procedure. The combined extracts were filtered through Buchner funnel and evaporated under reduced pressure at $50^{\circ}$ up to $90 \%$. Remaining liquid was successively partitioned with hexane, ethyl acetate (EtOAc) and n-butanol. The hexane, EtOAc and n-butanol extracts were separately pooled and evaporated to dryness under reduced pressure, while the aqueous layer was lyophilized to dryness. The fractions were designated as hexane fraction (HF), EtOAc fraction (EF), butanol fraction (BF) and aqueous fraction (AF).

\section{Cell cultures:}

The human breast cancer cell lines, MCF-7 and MDA-MB-468 and human placental choriocarcinoma (JEG-3) cells were obtained from American Type Culture Collection (ATCC, Rockville, MD, USA) and cultured in Dulbecco modified Eagle medium (DMEM, GIBCO BRL, Invitrogen, Grand Island, NY, USA) containing $10 \%(\mathrm{v} / \mathrm{v})$ fetal calf serum (Thermo Scientific Hyclone, Logan, UT, USA) $2 \mathrm{mM}$ glutamine, and antibiotics (200 U/1 of penicillin and $50 \mathrm{mg} / 1$ of streptomycin). It was maintained at $37^{\circ}$ in a humidified $5 \% \mathrm{CO}_{2}$ atmosphere.

\section{Cytotoxicity assay:}

In vitro cytotoxicity of the extract was determined using sulforhodamine-B (SRB) on MCF-7 and MDAMB-468 breast cancer cell lines and JEG-3 cells as described earlier ${ }^{[10]}$. Adriamycin purchased from Sigma-Aldrich, St. Louis, USA, was used as a standard.

\section{Intracellular ROS scavenging assay:}

Measurements of intracellular ROS levels in three cell lines were made using Bes- $\mathrm{H}_{2} \mathrm{O}_{2}-\mathrm{AC}$, a highly selective probe for $\mathrm{H}_{2} \mathrm{O}_{2}$. Bes- $\mathrm{H}_{2} \mathrm{O}_{2}-\mathrm{AC}$ can permeate through the cell membrane and is deacetylated inside the cells to give an impermeable product, $\mathrm{Bes}-\mathrm{H}_{2} \mathrm{O}_{2}$. Further intracellular ROS oxidizes Bes $-\mathrm{H}_{2} \mathrm{O}_{2}$ to give a fluorescent product difluorofluorescein. The intensity of fluorescence decides the oxidative stress of the cells. Decrease in fluorescence is expected to be produced by compounds which can scavenge ROS. This assay was performed using a previously described method ${ }^{[11]}$.

\section{Aromatase enzyme activity:}

In vitro enzyme activity assays were performed on JEG-3 cells using both a direct aromatase and indirect aromatase assay systems as described previously with minor modifications ${ }^{[12]}$. In the direct aromatase assay, the $\mathrm{EF}$ and $\mathrm{BF}$ were mixed with $54 \mathrm{nM}$ $(1 \beta-3 \mathrm{H})$ androstenedione; the cells were treated with this mixture for $2 \mathrm{~h}$.

In the indirect aromatase assay, cells were pretreated with the $\mathrm{EF}$ and $\mathrm{BF}$ for $18 \mathrm{~h}$, and then exposed to $54 \mathrm{nM}(1 \beta-3 \mathrm{H})$ androstenedione for another $1 \mathrm{~h}$. After incubation at $37^{\circ}$ the supernatant was collected and extracted with chloroform. The aqueous supernatant 
was mixed with $5 \%$ charcoal $/ 0.5 \%$ dextran and incubated for $15 \mathrm{~min}$. The mixture was centrifuged at $14000 \mathrm{~g}$ for $5 \mathrm{~min}$, and the aromatase activity of the supernatant was measured using a liquid scintillation counter (LS-6500, Beckman counter, CA, USA) with a liquid scintillation cocktail (PerkinElmer ${ }^{\circledR}$, MA, USA).

\section{Determination of $17 \beta$-oestradiol synthesis:}

JEG-3 cells were seeded in a 24-well plate and were cultured overnight. Next day, EF and BF were added to the cells in phenol red-free DMEM with $5 \%$ charcoaldextran-treated fetal bovine serum for $12 \mathrm{~h}$. After this incubation, testosterone (10 $\mathrm{nM})$ was added to each well, and the cells were incubated for $12 \mathrm{~h}$. The culture media were then collected and stored at $-20^{\circ}$. Levels of $17 \beta$-oestradiol in the media were quantified using a competitive enzyme-immunoassay, according to the manufacturer's instructions (Cayman Chemical, Ann Arbor, MI, USA). The enzymatic reaction was measured at $412 \mathrm{~nm}$ using a plate reader (BioTek, Winooski, US).

\section{Isolation of components:}

EF was subjected to silica gel column chromatography eluted with increasing polarity of hexane and EtOAc for the isolation of components. Total 6 fractions were collected and were further purified. Chemical structures of all the isolated compounds was confirmed by nuclear magnetic resonance (NMR) and mass spectroscopy (MS). While fraction 1 was purified using Sephadex LH 20 using $90 \%$ ethanol as mobile phase to obtain protocatechuic acid $(37 \mathrm{mg})$, fraction 2 was further purified using silica gel column chromatography and hexane:EtOAc as mobile phase to give p-coumaric acid $(84 \mathrm{mg})$. Fraction 3 was purified on an octadecylsilane (ODS) column using $50 \%$ methanol $(\mathrm{MeOH})$ as the eluting phase to give ferulic acid $(62 \mathrm{mg})$. Sephadex LH-20 was used to purify fraction 4 using $100 \%$ $\mathrm{MeOH}$ to give gallic acid $(28 \mathrm{mg})$. Pure compounds were obtained from fraction 5 using preparative thinlayer chromatography, using chloroform: $\mathrm{MeOH}: \mathrm{H}_{2} \mathrm{O}$ (8:1:0.3) that yielded vanillic acid $(11 \mathrm{mg})$ and p-hydroxybenzoic acid (14 mg). Fraction 6 was eluted through Sephadex LH-20 using $\mathrm{MeOH}: \mathrm{H}_{2} \mathrm{O}$, which yielded three fractions viz. fraction 6.1 , fraction 6.2 and fraction 6.3. Out of which fraction 6.2 was further purified using ODS column using $\mathrm{CH}_{3} \mathrm{CN}: \mathrm{H}_{2} \mathrm{O}$ that yielded chlorogenic acid (100 mg; fig. 1).

\section{RESULTS AND DISCUSSION}

Results of cytotoxic activity evaluation performed on 3 cell lines at 4 different concentrations (10, 20, 40 and $80 \mu \mathrm{g} / \mathrm{ml}$ ) revealed that on MCF-7 cells, EF and BF were cytotoxic at $20 \mu \mathrm{g} / \mathrm{ml}$ and cytocidal at 40 and

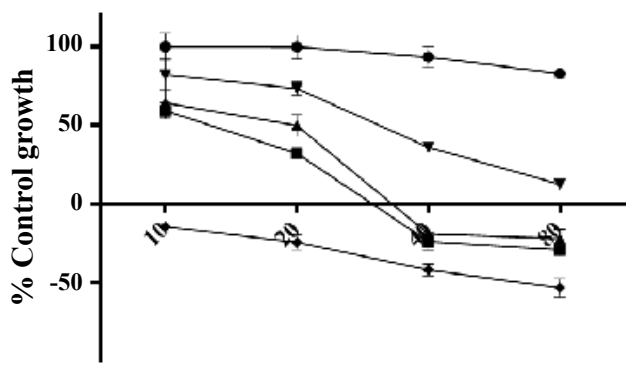

Fraction Concentrations' $(\mu \mathrm{g} / \mathrm{ml})$

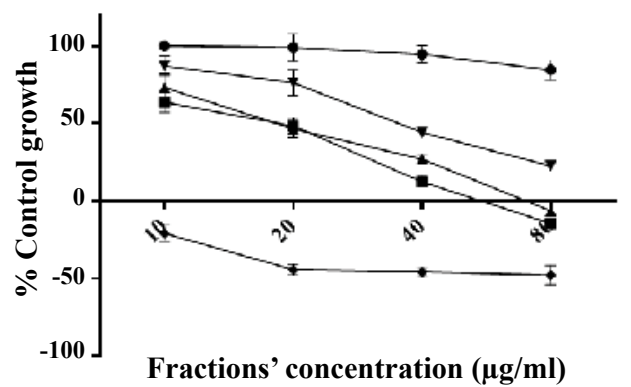

b.

a.

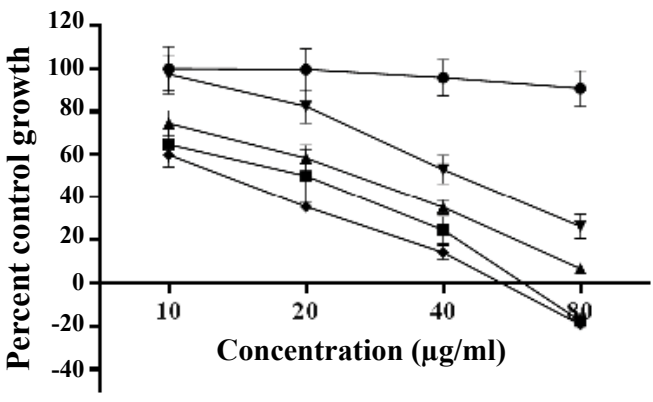

c.

Fig 1: Cytotoxicity of different fractions of $P$. persica crude extract on three cell lines

- •- Hexane fraction; - - ethyl acetate fraction; $-\Delta-$ butanol fraction; $-\nabla-$ aqueous fraction, (a) Oestrogen receptor positive (MCF-7), — — adriamycin (b) oestrogen receptor negative (MDA-MB-468), — — adriamycin and (c) Human placenta choriocarcinoma cell lines, $-\bullet-$ exemastane. Results were expressed as mean \pm SD $(n=3)$ for each group 
$80 \mu \mathrm{g} / \mathrm{ml}$; whereas, on MDA-MB-468, EF and BF were cytocidal at $80 \mu \mathrm{g} / \mathrm{ml}$ and cytostatic at $>20 \mu \mathrm{g} / \mathrm{ml}$. Adriamycin was used as a standard for both cell lines. On JEG-3 cell line, EF showed cytostatic effect at 20 and $40 \mu \mathrm{g} / \mathrm{ml}$ and cytocidal effect at $80 \mu \mathrm{g} / \mathrm{ml}$. BF on JEG-3 cells showed cytostatic effect at $40 \mu \mathrm{g} / \mathrm{ml}$ and cytocidal effect at $80 \mu \mathrm{g} / \mathrm{ml}$. Moderate activity was exhibited by AF with a cytostatic effect on all three cell lines at 40 and $80 \mu \mathrm{g} / \mathrm{ml}$ of concentrations, whereas HF showed least cytotoxicity activity on all three cell lines (fig. 1). Exemestane was used as a standard for JEG-3 cells as these cells express the aromatase in more quantity than MCF-7 cell line. These cytotoxic effects of EF and BF on different cell lines could be due to the presence of high amount of total phenolic and flavonoid contents as reported earlier ${ }^{[13]}$. Present findings agree with the reported work, which indicated that different fractions of peach exhibited potent antiproliferative activity against oestrogen-independent MDA-MB-435 cells, but weak activity against oestrogen-dependent MCF-7 cells ${ }^{[14]}$.

Natural polyphenols have long been attributed for their antioxidant activities. In fact, plant extracts contain a mixture of various phenolic and nonphenolic compounds. It has also been reported that these extracts, which are antioxidant in nature also show anticancer properties due to the presence of their polyphenol compounds ${ }^{[15]}$. In one of our previous investigations, observed that $\mathrm{EF}$ and $\mathrm{BF}$ of $P$. persica contain very high amount of total phenol and total flavonoid, whereas, HF and AF had less amount. Cytotoxicity activity of four test fractions and reported content of total phenol and flavonoid concord with each other ${ }^{[9]}$.

Excessive production of ROS by dysfunctioning cell organelles would lead to the activation of several pathways, which might further cause cancer ${ }^{[16]}$. Therefore, a need existed to inhibit the intracellular ROS to prevent breast cancer. ROS-induced pathways persistently get expressed in many types of cancers, in which these would result in cell proliferation, differentiation, and inflammation ${ }^{[17]}$. Therefore, it is expected that inhibiting the intracellular ROS might prevent breast cancer.

Intracellular ROS scavenging activity of the test fractions in different breast cancer and human placenta choriocarcinoma cells was evaluated. On all the three cell lines, EF and BF scavenged intracellular ROS at concentrations $>50 \mu \mathrm{g} / \mathrm{ml}$ (fig. 2). Both the fractions reduced the mean fluorescence intensity significantly in a dose-dependent manner. On MCF-7 cell line, at $200 \mu \mathrm{g} / \mathrm{ml}$, EF reduced the fluorescence intensity (MFI) to 0.75 , whereas, $\mathrm{BF}$ reduced it to 1.01 in comparison to control $+\mathrm{H}_{2} \mathrm{O}_{2}$ cells. AF and BF on MDA-MB-468 cells reduced the MFI to 1.05 and 1.48, respectively. On JEG-3 cells, EF reduced the MFI to 0.87 and BF reduced it to 1.19. A previous study reported that $P$. persica extract scavenged intracellular ROS in pheochromocytoma cells $^{[18]}$. Kang et al. reported that the ethanol extract of $P$. mume scavenged intracellular ROS in myeloblast cells at a concentration of $500 \mu \mathrm{g} / \mathrm{ml}^{[19]}$. However, there was no report on the ROS scavenging potential of $P$. persica extract in breast cancer and JEG-3 cells.

Aromatase is an enzyme that is responsible for synthesizing oestrogen from androgen ${ }^{[20]}$. It is found that aromatase activity is higher in breast tumours. In fact, there is a significant correlation between aromatase and the presence of tumours in breast tissues. A very high level of aromatase expression is also found in placenta during pregnancy. Therefore, JEG-3 cells are often used in the breast cancer study ${ }^{[2]}$. In the present investigation also inhibition of aromatase activity was considered as a potential target mechanism to prevent breast cancer.

$\mathrm{EF}$ and $\mathrm{BF}$ were further evaluated for aromatase inhibition activity as these fractions were found potentially more cytotoxic in comparison to the other two fractions. In the direct method it was observed that EF significantly inhibited the aromatase activity at $>50 \mu \mathrm{g} / \mathrm{ml}$; whereas, BF was equally effective at the concentration of $>100 \mu \mathrm{g} / \mathrm{ml}$. At $200 \mu \mathrm{g} / \mathrm{ml}$ concentration EF produced $51.20 \pm 1.98 \%$ inhibition, while at the same concentration, BF inhibited the enzyme by $60.25 \pm 2.87 \%$ as compared to that of cells exposed to the vehicle control (fig. 3a).

With respect to indirect method, at $200 \mu \mathrm{g} / \mathrm{ml}$, EF inhibited $48 \pm 1.85 \%$ and BF inhibited $59.21 \pm 2.97 \%$ of aromatase activity, respectively (fig. 3b). Similar to these findings, some of the flavonoids isolated from heartwood and resin of $P$. avium also showed inhibitory activity on aromatase ${ }^{[21]}$. In addition, $P$. africana bark extract has also shown potent antiaromatase activity ${ }^{[22]}$. One of the reports showed that the extract of Ginkgo biloba, which contained flavones inhibited aromatase and exerted antitumor effects on breast cancer cells ${ }^{[23]}$.

At the highest concentration of $200 \mu \mathrm{g} / \mathrm{ml}$ tested, EF inhibited oestrogen synthesis to $43.95 \%$ and BF inhibited to $65.25 \%$ as compared to the control (fig. 3c). Statistically $60 \%$ of premenopausal and 


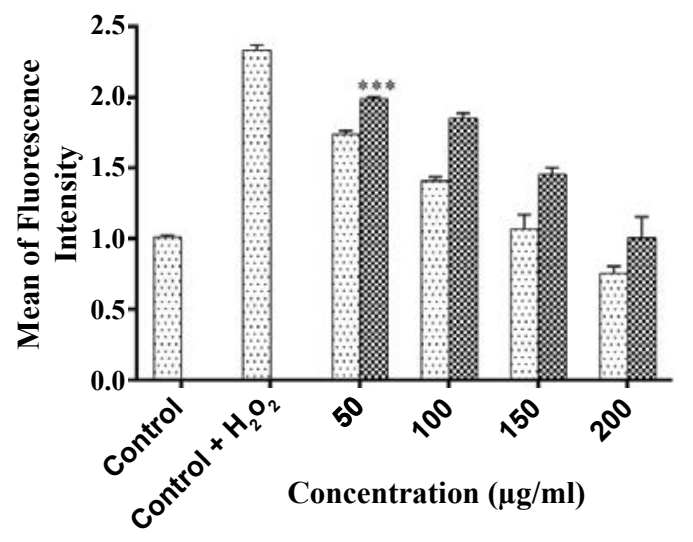

a.

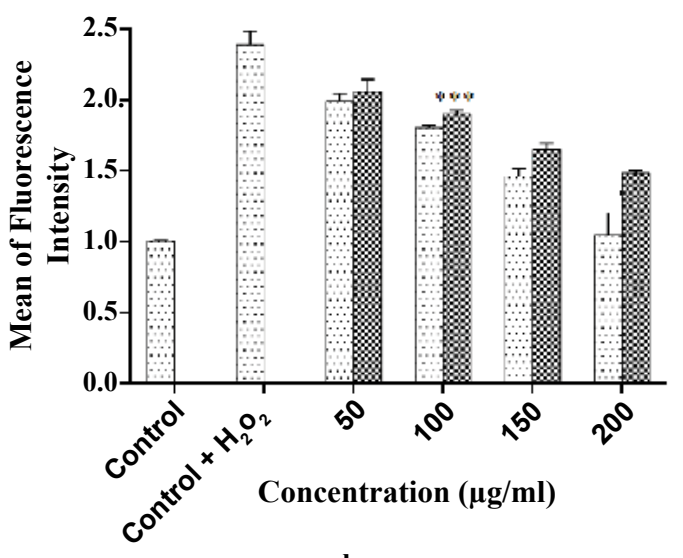

b.

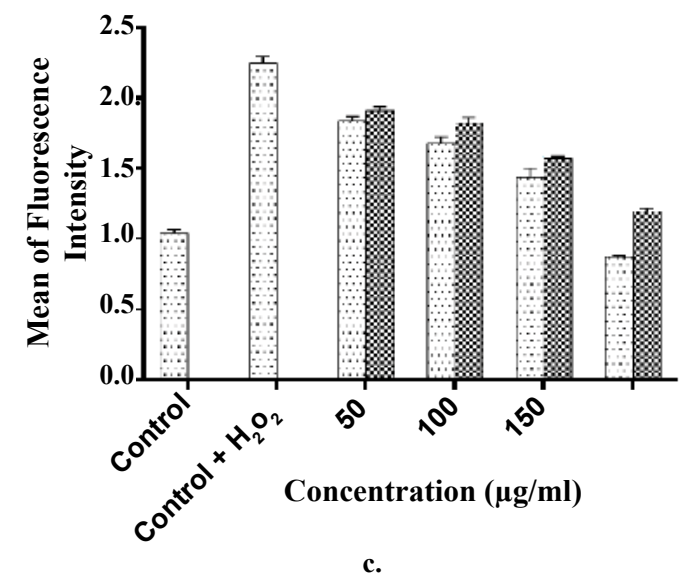

Fig. 2: Fluorescence intensity of three cell lines treated with different concentrations of sample and with $\mathrm{H}_{2} \mathrm{O}_{2}$ Ethyl acetate fraction; $\$$ butanol fraction, (a) oestrogen receptor positive (MCF-7), (b) oestrogen receptor negative (MDAMB-468) and (c) human placenta choriocarcinoma cell lines. All values are expressed as means \pm SDs $(n=3)$. Significant difference from control $+\mathrm{H}_{2} \mathrm{O}_{2}$ was observed by ANOVA where, $* * * \mathrm{p}<0.001$

$75 \%$ of postmenopausal patients are believed to have oestrogen-dependent carcinomas ${ }^{[24]}$. Aromatase converted androstenedione to oestradiol and the level of aromatase has a direct correlation with oestrogen synthesis. It has been reported that level of aromatase is expressed more in breast tumor and placenta of pregnant women ${ }^{[25,26]}$. In this study significant aromatase inhibitory activity of EF and BF was observed. This is similar to a compound found in P. laurocerasus that is known to show antiaromatase activity and play an important role in the depletion of oestrogen synthesis ${ }^{[27,28]}$. Kim et al. reported antioestrogenic activity of many medicinal plants and showed that $P$. persica exhibited solvent-dependent antioestrogenic activity $^{[29]}$.

In this study, compounds isolated from EF and identified through MS and NMR analyses as protocatechuic acid, p-coumaric acid, ferulic acid, gallic acid, vanillic acid, p-hydroxybenzoic acid and chlorogenic acid. This appears to be the first report that indicates the presence of all these 7 compounds in EF of P. persica whole fruit. Of course, these seven compounds are already reported in literature, but from some other plant extracts ${ }^{[30-34]}$.

The p-coumaric acid was obtained as white powder and the melting point (MP) was $203-205^{\circ}$. Its ${ }^{1} \mathrm{HNMR}$ data were $\left(400 \mathrm{MHz}, \mathrm{DMSO}-\mathrm{d}_{6}\right): 12.09$ (s, broad, 1H), 9.18, (s, broad, 1H), $7.34(\mathrm{~d}, 1 \mathrm{H}, \mathrm{J}=15.8 \mathrm{~Hz})$, $7.16(\mathrm{t}, 1 \mathrm{H}, \mathrm{J}=7.7 \mathrm{~Hz}), 6.97(\mathrm{~d}, 1 \mathrm{H}, \mathrm{J}=7.7 \mathrm{~Hz}), 6.95$ $(\mathrm{d}, 1 \mathrm{H}, \mathrm{J}=2.2 \mathrm{~Hz}), 6.74(\mathrm{dd}, 1 \mathrm{H}, \mathrm{J}=2.2,7.7 \mathrm{~Hz})$ and 6.45 $\left(\mathrm{d}, 1 \mathrm{H}, \mathrm{J}=15.8 \mathrm{~Hz}\right.$ ). MS (ESI) calculated for $\mathrm{C}_{6} \mathrm{H}_{6} \mathrm{O}_{3}$ was $\mathrm{m} / \mathrm{z}: 164^{[30]}$. Chlorogenic acid was obtained as a white powder and the MP was found to be 200$205^{\circ} .{ }^{1} \mathrm{HNMR}$ data were $\left(400 \mathrm{MHz}, \mathrm{DMSO}-\mathrm{d}_{6}\right): 9.62$ (1H, s, H- 4'), 9.19 (1H, s, 3'-OH), 7.42 (1H, d, J=16.0 Hz, H-7'), 7.03 (1H, brs, H-2'), 6.98 (1H, dd, J=8.0, 2.0 Hz, H-6'), $6.76\left(1 \mathrm{H}, \mathrm{d}, \mathrm{J}=8.0 \mathrm{~Hz}, \mathrm{H}-5^{\prime}\right), 6.15(1 \mathrm{H}, \mathrm{d}$, $\left.\mathrm{J}=16.0 \mathrm{~Hz}, \mathrm{H}-8^{\prime}\right), 5.06(1 \mathrm{H}$, ddd, $\mathrm{J}=10.0,6.0 \mathrm{~Hz}, \mathrm{H}-3)$, $3.92(1 \mathrm{H}$, brs, H-5), $3.42(1 \mathrm{H}$, brs, H-4), 2.03-1.77 $(4 \mathrm{H}, \mathrm{m}, \mathrm{H}-2 / \mathrm{H}-6)$. MS (ESI) calculated for $\mathrm{C}_{6} \mathrm{H}_{6} \mathrm{O}_{3}$ was $\mathrm{m} / \mathrm{z}: 354^{[30]}$. 


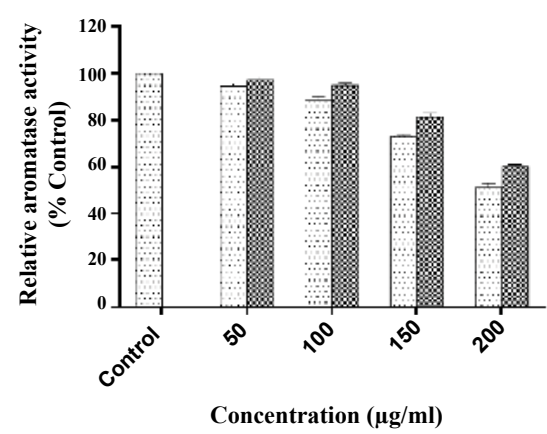

a.

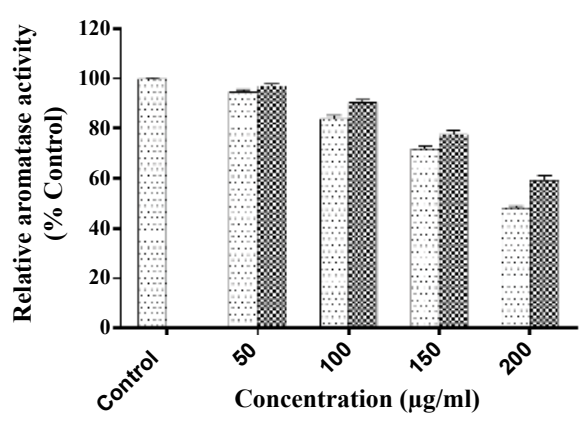

b.

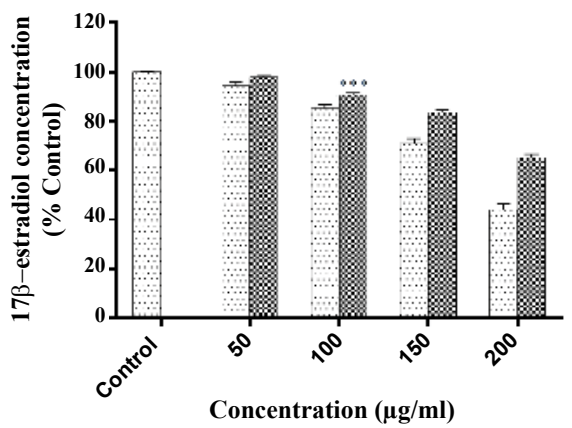

c.

Fig. 3: Aromatase activity of EF and BF on JEG-3 cells

Ethyl acetate fraction (EF); \& butanol fraction (BF), (a) direct, (b) indirect effects and (c) inhibitory effects on 17 $\beta$-oestradiol biosynthesis. The results are expressed as the mean $\pm \operatorname{SDs}(n=3)$. Significant difference from control was observed by ANOVA where, $* * * \mathbf{p}<0.001$

p-Hydroxybenzoic acid was obtained as a white amorphous powder and the MP was 203-205 . Its ${ }^{1} \mathrm{HNMR}$ data were $(400 \mathrm{MHz}$, DMSO-d $): 7.86$ $(2 \mathrm{H}, \mathrm{d}, \mathrm{J}=8.8 \mathrm{~Hz}), 6.80(2 \mathrm{H}, \mathrm{d}, \mathrm{J}=8.8 \mathrm{~Hz})$. The molecular formula was established as $\mathrm{C}_{7} \mathrm{H}_{6} \mathrm{O}_{3}$ by MS (ESI) $\mathrm{m} / \mathrm{z}$ : $137.2[\mathrm{M}-\mathrm{H}]$.

The data agreed well with the reported compound, p-hydroxybenzoic acid ${ }^{[31]}$. Gallic acid was recrystallized from $\mathrm{MeOH}$ as white needles with $\mathrm{MP}$ of $253-255^{\circ}$. Its ${ }^{1} \mathrm{H}$ NMR data were, (400 MHz, DMSO-d $\left.{ }_{6}\right): 6.91(1 \mathrm{H}, \mathrm{s}, \mathrm{H}-2,6)$. The MS (ESI) showed ion at $\mathrm{m} / \mathrm{z} 169.3[\mathrm{M}-\mathrm{H}]^{-}$, corresponding to the molecular formula of $\mathrm{C}_{7} \mathrm{H}_{6} \mathrm{O}_{5}$. Based on these data, compound 4 was identified as gallic acid consistent with the data reported ${ }^{[32]}$. Ferulic acid was obtained as a white powder with an MP of $170-172^{\circ} .{ }^{1} \mathrm{H}$ NMR data were $\left(400 \mathrm{MHz}, \mathrm{DMSO}-\mathrm{d}_{6}\right): 7.53$ (d, J=15.56 Hz, 1H, H3'), 6.99 (d, J=7.96 Hz, 1H, H6"), 6.91 (s, 1H, H2"), $6.84\left(\mathrm{~d}, \mathrm{~J}=8.14 \mathrm{~Hz}, 1 \mathrm{H}, \mathrm{H} 5^{\prime \prime}\right), 6.36$ (s, 2H, OH, NH), $6.29\left(\mathrm{~d}, \mathrm{~J}=15.54 \mathrm{~Hz}, 1 \mathrm{H}, \mathrm{H} 2^{\prime}\right), 4.14$ (s, 2H, H1) and 3.81 (s, 3H, CH3). MS (ESI) calculated for $\mathrm{C}_{6} \mathrm{H}_{6} \mathrm{O}_{3}$ was $\mathrm{m} / \mathrm{z}$ : 194. This compound was identified as ferulic acid sine the data agreed with the data reported earlier ${ }^{[33]}$.

Protocatechuic acid obtained as a white powder showed MP at $200-202^{\circ} .{ }^{1} \mathrm{H}$ NMR data were $(400$
MHz, DMSO-d $): 7.33(1 \mathrm{H}, \mathrm{s}, \mathrm{H} 2), 6.77(1 \mathrm{H}, \mathrm{d}, \mathrm{J}=8.0$ $\mathrm{Hz}, \mathrm{H} 5)$ and $7.28(1 \mathrm{H}, \mathrm{d}, \mathrm{J}=8.0 \mathrm{~Hz}, \mathrm{H} 6)$. MS (ESI) calculated for $\mathrm{C}_{6} \mathrm{H}_{6} \mathrm{O}_{3}$ was $\mathrm{m} / \mathrm{z}: 154$. This compound was identified as protocatechuic acid as the data agreed with the data reported earlier ${ }^{[34]}$. Vanillic acid obtained as a white powder had an MP at $201-203^{\circ} .{ }^{1} \mathrm{H}$ NMR data was (400 MHz, DMSO-d $)$ : $7.42(1 \mathrm{H}, \mathrm{s}, \mathrm{H} 2), 6.79$ (1H, d, J 8.0 Hz, H5), 7.41 (1H, d, J 9.2 Hz, H6), 3.78 $(3 \mathrm{H}, \mathrm{s}, \mathrm{OCH} 3)$. MS (ESI) calculated for $\mathrm{C}_{6} \mathrm{H}_{6} \mathrm{O}_{3}$ was $\mathrm{m} / \mathrm{z}$ : 168. This compound was identified as vanillic acid that also agreed with the data reported earlier ${ }^{[34]}$.

As shown in fig. 4, gallic acid was found to be most effective in inhibiting the growth of JEG-3 cells (inhibited more than $50 \%$ cells at $20 \mu \mathrm{g} / \mathrm{ml}$ ) which also showed cytocidal effect at $80 \mu \mathrm{g} / \mathrm{ml}$, which was similar to the cytotoxic effect of the standard exemastane. Chlorogenic acid also showed cytostatic effect and was able to inhibit $50 \%$ cell growth at $40 \mu \mathrm{g} / \mathrm{ml}$. This finding on the cytotoxicity of gallic acid and chlorogenic acid agreed with our previous findings on breast cancer cell lines, MCF-7 and MDA-MB-468 $8^{[35]}$.

In conclusion, the present study revealed that EF and BF of P. persica showed a wide range of cytotoxic and antioxidant activities through aromatase inhibition and scavenging intracellular ROS in breast cancer and 


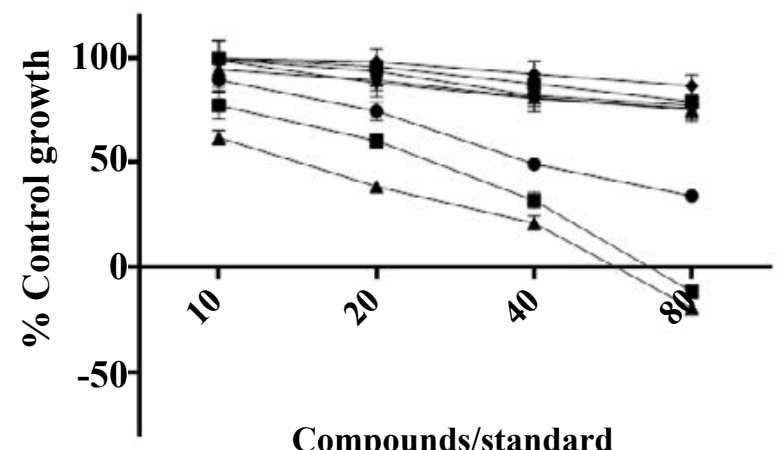

Compounds/standard

concentrations $(\mu \mathrm{g} / \mathrm{ml})$

Fig 4: Cytotoxicity study of isolated compounds on JEG-3 cells -•- Chlorogenic acid; - - gallic acid; $-\Delta-$ ferulic acid;

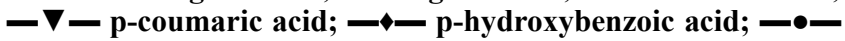
protocatechuic acid; $-\square-$ vanillic acid; $-\Delta-$ exemastane. The results were expressed as the mean $\pm S D(n=3)$

human placenta choriocarcinoma cell lines. Present study further indicated that the EF also regulated oestrogen synthesis in human placenta choriocarcinoma cells. Further, gallic acid isolated from EF showed better cytotoxic activity in comparison to adriamycin. The compounds isolated from these fractions could be further studied to evaluate their potential to prevent breast cancer. As the $P$. persica fruit extract or its active compounds appeared to be acting through dual mechanisms of improving antioxidant system and inhibiting aromatase, it could potentially be used as a therapeutic agent for the treatment of breast cancer.

\section{Acknowledgements:}

Financial assistance from the Department of Science and Technology, India for the award of INSPIREDST SRF to Naveen Dhingra (IF110047) is gratefully acknowledged. We would also like to thank ACTREC Mumbai for performing the SRB assay, Panjab University, Chandigarh, India for Mass and NMR spectroscopy data and Dr. Renu Rajesh for identifying the plant material collected.

\section{Conflict of interest:}

There is no conflict of interest among authors.

\section{REFERENCES}

1. Lee CK, Park KK, Hwang JK, Lee SK, Chung WY. The pericarp extract of Prunus persica attenuates chemotherapyinduced acute nephrotoxicity and hepatotoxicity in mice. $\mathrm{J}$ Med Food 2008;11:302-06.

2. Chen S. Aromatase and breast cancer. Front Biosci 1998;3:d922-33.

3. Reuter S, Gupta SC, Chaturvedi MM, Aggarwal BB. Oxidative stress, inflammation, and cancer: How are they linked? Free Radic Biol Med 2010;46:1603-16.
4. Dhingra N, Sharma R, Kar A. Oxidative stress and carcinogenesis: prevention by antioxidative phytochemicals acting on different molecular targets. Int J Pharm Sci Rev Res 2014;25:236-45.

5. Cazzaniga M, Bonanni B. Breast cancer chemoprevention: old and new approaches. J Biomed Biotechnol 2012;2012:985620.

6. Renoir JM, Marsaud V, Lazennec G. Estrogen receptor signaling as a target for novel breast cancer therapeutics. Biochem Pharmacol 2013;85:449-65.

7. Cheung AM, Heisey R, Srighanthan J. Breast cancer and osteoporosis. Curr Opin Endocrinol Diabetes Obes 2013;20:532-8

8. Powles TJ, Hickish T, Kanis JA, Tidy A, Ashley S. Effect of tamoxifen on bone mineral density measured by dualenergy X-ray absorptiometry in healthy premenopausal and postmenopausal women. J Clin Oncol 1996;14:78-84.

9. Dhingra N, Sharma R, Kar A. Towards further understanding on the antioxidative activities of Prunus persica fruit: A comparative study with four different fractions. Spectrochim Acta A Mol Biomol Spectrosc 2014;132:582-7.

10. Dhingra N, Sharma R, Kar A. Antioxidative and antiproliferative activities of isolated compounds from Prunus domestica: an in vitro study. Int J Phytomed 2013;5:341-6.

11. Li Y, Nishimura T, Teruya K, Maki T, Komatsu T, Hamasaki T, et al. Protective mechanism of reduced water against alloxaninduced pancreatic $\beta$-cell damage: Scavenging effect against reactive oxygen species. Cytotechnology 2002;40:139-49.

12. Lephart ED, Simpson ER. Assay of aromatase activity. Methods Enzymol 1991;206:477-83.

13. Carocho M, Ferreira IC. The role of phenolic compounds in the fight against cancer--a review. Anticancer Agents Med Chem 2013;13:1236-58.

14. Vizzotto M, Porter W, Byrne D, Cisneros-Zevallos L. Polyphenols of selected peach and plum genotypes reduce cell viability and inhibit proliferation of breast cancer cells while not affecting normal cells. Food Chem 2014;164:363-70.

15. Lewandowska H, Kalinowska M, Lewandowski W, Stępkowski TM, Brzóska K. The role of natural polyphenols in cell signaling and cytoprotection against cancer development. J Nutr Biochem 2016;32:1-19.

16. Liou G-Y, Storz P. Reactive oxygen species in cancer. Free Radic Res 2015;44:1-31.

17. Waris $G$, Ahsan H. Reactive oxygen species: role in the development of cancer and various chronic conditions. J Carcinog 2006;5:1-8.

18. Mokrani A, Krisa S, Cluzet S, Da Costa G, Temsamani H, Renouf E, et al. Phenolic contents and bioactive potential of peach fruit extracts. Food Chem 2016;202:212-20.

19. Kang JS, Kim DJ, Kim GY, Cha HJ, Kim S, Kim HS, et al. Ethanol extract of Prunus mume fruit attenuates hydrogen peroxide-induced oxidative stress and apoptosis involving Nrf2/HO-1 activation in $\mathrm{C} 2 \mathrm{C} 12$ myoblasts. Rev Bras Farmacogn 2016;26:184-90.

20. Simpson ER, Mahendroo MS, Means GD, Kilgore MW, Hinshelwood MM, Graham-Lorence S, et al. Aromatase cytochrome P450, the enzyme responsible for estrogen biosynthesis. Endocr Rev 1994;15:342-55.

21. McNulty J, Nair JJ, Bollareddy E, Keskar K, Thorat A, Crankshaw DJ, et al. Isolation of flavonoids from the heartwood and resin of Prunus avium and some preliminary biological investigations. Phytochemistry 2009;70:2040-6.

22. Farley M. Anti-aromatase pharmaceutical composition for 
controlling testosterone/estrone ratios. United States patent US20030190376 A1. 2003.

23. Park YJ, Ahn HY, Kim HR, Chung KH, Oh SM. Ginkgo biloba extract EGb 761-mediated inhibition of aromatase for the treatment of hormone-dependent breast cancer. Food Chem Toxicol 2016;87:157-65.

24. Green SJ. Steroid receptors and new (anti-) steroidal agents: modulation of oestrogen receptor activity by oestrogens and anti-oestrogens. J Steroid Biochem Mol Biol 1990;37:747-51.

25. James VH, McNeill JM, Lai LC, Newton CJ, Ghilchik MW, Reed MJ. Aromatase activity in normal breast and breast tumor tissues: in vivo and in vitro studies. Steroids 1987;50:269-79.

26. Bates SE, Davidson NE, Valverius EM, Freter CE, Dickson $\mathrm{RB}$, Tam JP, et al. Expression of transforming growth factor alpha and its messenger ribonucleic acid in human breast cancer: its regulation by estrogen and its possible functional significance. Mol Endocrinol 1988;2:543-55.

27. Gnoatto SC, Dassonville-Klimpt A, Da Nascimento S, Galéra $\mathrm{P}$, Boumediene K, Gosmann G, et al. Evaluation of ursolic acid isolated from Ilex paraguariensis and derivatives on aromatase inhibition. Eur J Med Chem 2008;43:1865-77.

28. Ibrahim B, Francis S. Ubiquitous Ursolic Acid: A Potential Pentacyclic Triterpene Natural Product. J Pharmacogn Phytochem 2013;2:214-22.
29. Kim IG, Kang SC, Kim KC, Choung ES, Zee OP. Screening of estrogenic and antiestrogenic activities from medicinal plants. Environ Toxicol Pharmacol 2008;25:75-82.

30. Durust N, Ozden S, Umur E, Durust Y, Kucukislamoglu M. The Isolation of Carboxylic Acids from the Flowers of Delphinium formosum. Turk J Chem 2001;25:93-7.

31. Yayli N, Yildirim N, Usta A, Ozkurt S, Akgun V. Chemical Constituents of Campanula lactiflora. Turk J Chem 2003;27:749-55.

32. Eldahshan OA. Isolation and Structure Elucidation of Phenolic Compounds of Carob Leaves Grown in Egypt. Cur Res J Bio Sci 2011;3:52-5.

33. Jiaranaikulwanitch J, Govitrapong P, Fokin VV, Vajragupta O. From Bace1 inhibitor to multifunctionality of tryptoline and tryptamine triazole derivatives for Alzheimer's disease. Molecules 2012;17:8312-33.

34. Cai T, Qi W, Yang L, Tu G, Yang R, Xie K, et al. Chemical constituents of Pseudolarix kaempferi Gord. J Chin Pharm Sci 2012; 21: 428-35.

35. Dhingra N, Sharma R. Diversified Antioxidant, Intercellular Reactive Species, Scavenging, Antiproliferative and Molecular Docking Study of Some Phytochemicals. Int J Pharm Sci Res 2015;6(1):38-40. 